\title{
Effect of Cothurnia variabilis and Epistylis gammari (Ciliophora: Peritrichia) on Metabolic Rate of the Crayfish Cambarellus (Cambarellus) montezumae
}

\author{
Mireya Ramírez-Ballesteros ${ }^{1,2, *}$, René Cárdenas-Vázquez ${ }^{3}$, Alfonso Lugo-Vázquez ${ }^{4}$ and Rosaura Mayén-Estrada ${ }^{1}$ \\ 1 Laboratorio de Protozoología, Departamento de Biología Comparada, Facultad de Ciencias, Universidad \\ Nacional Autónoma de México (UNAM), Circuito Ext. s/n. Ciudad Universitaria, Av. Universidad 3000, \\ Coyoacán, Ciudad de Mexico 04510, Mexico; rme2@ciencias.unam.mx \\ 2 Posgrado en Ciencias Biológicas, Facultad de Ciencias, UNAM, Ciudad de Mexico 04510, Mexico \\ 3 Laboratorio de Biología Animal Experimental. Departamento de Biología Celular, Facultad de Ciencias, \\ UNAM, Ciudad de Mexico 04510, Mexico; rcv@ciencias.unam.mx \\ 4 Grupo de Limnología Tropical, Unidad de Investigación Interdisciplinaria en Ciencias de la Salud y la \\ Educación, FES Iztacala, UNAM, Av. de los Barrios No. 1, Los Reyes Iztacala, Tlalnepantla 54090, Mexico; \\ lugov@unam.mx \\ * Correspondence: mballesteros@ciencias.unam.mx
}

\section{check for} updates

Citation: Ramírez-Ballesteros, M.; Cárdenas-Vázquez, R.; LugoVázquez, A.; Mayén-Estrada, R. Effect of Cothurnia variabilis and Epistylis gammari (Ciliophora: Peritrichia) on Metabolic Rate of the Crayfish Cambarellus (Cambarellus) montezumae. Diversity 2021, 13, 333. https:// doi.org/10.3390/d13070333

Academic Editors: Martina Schrallhammer and Michael Wink

Received: 7 June 2021

Accepted: 14 July 2021

Published: 19 July 2021

Publisher's Note: MDPI stays neutral with regard to jurisdictional claims in published maps and institutional affiliations.

Copyright: (c) 2021 by the authors. Licensee MDPI, Basel, Switzerland. This article is an open access article distributed under the terms and conditions of the Creative Commons Attribution (CC BY) license (https:// creativecommons.org/licenses/by/ $4.0 /)$.

\begin{abstract}
Peritrichs usually settle on the external surface and gills of crustaceans. However, their physiological effect on the host has not been studied. Respiratory rate is a susceptible index for some factors that affect an organism. To test if ciliates attached to the crustacean gills have a physiological effect, we measured crustacean oxygen consumption in a closed system. Crayfish Cambarellus (Cambarellus) montezumae were collected in Lago Xochimilco in Mexico City and were isolated in chambers. Two peritrich species, Cothurnia variabilis (32.5\%) and Epistylis gammari (67.5\%), were observed on the gills. The metabolic rate was evaluated by oxygen consumption with a polarimetric oximeter. Statistical analyses demonstrated that a density of ciliates attached to the gills of the crayfish above $\sim 50$ individuals increased oxygen consumption with a positive correlation to epibiont density. We conclude that $C$. variabilis and E. gammari ciliate epibionts attached to the gill of the crayfish Cambarellus (Cambarellus) montezumae cause an increase in metabolic rate.
\end{abstract}

Keywords: oxygen consumption; decapod crustaceans; epibiosis; gills; peritrichs

\section{Introduction}

Respiratory rate, measured as oxygen consumption, is used as an indicator of metabolic rate, a reliable parameter to assess an organism's physiological state [1]. In decapod crustaceans, the exchange of respiratory gases and ions occurs when water is drawn into the branchial chambers and circulated over the gill surfaces [2]. External factors (as salinity, light, oxygen, and temperature) and internal factors (as activity, nutrients, and molt) affect crustacean's respiratory rate $[3,4]$. It has been reported that oxygen demand depends fundamentally on the water temperature and body weight [5]; temperature is the main parameter that influences the metabolic rate of organisms $[4,6]$.

The respiratory rate can be so sensitive that its determination is a tool that helps us to know directly how an animal is performing in its interaction with the environment [7]. Oxygen consumption measurement can be used as an indicator of the effect of epibionts on the energy demands of host aquatic organisms.

In aquatic environments, epibiosis is frequent [8,9]. It is a facultative and interspecific association of two organisms, the epibiont, and the basibiont. The epibiont is the organism that attaches to an organic substrate, and the basibiont is the organism that serves as substrate $[8,10,11]$. Ciliates are common as crustacean epibionts since the crustacean body provides a suitable substrate for colonization, dispersion, shelter, and nutriment. Some 
ciliate species attach themselves to the gills of crustaceans by a stalk formed by glycoproteins, as species of the genera Epistylis Ehrenberg, 1830 and Cothurnia Ehrenberg, 1831. Ciliates have been recorded as epibionts in the gill of crustaceans since the 19th century. For example, Lightner [12] reported that Epistylis sp., Vorticella sp., and Zoothamnium sp. interfere with the locomotion and feeding of the larvae, causing stress and death in penaeid shrimp and prawns. Overstreet [13] observed that Zoothamnium sp. could cause mortality in species of the genus Penaeus (Fabricius, 1798). However, these and other studies have not provided evidence for the effects of attached peritrichs ciliates on crayfish physiology.

This work aims to analyze the possible influence on the metabolic rate of crayfish Cambarellus (Cambarellus) montezumae (de Saussure, 1857), of two species of peritrichs ciliates attached to the gills. The hypothesis is that crayfish oxygen consumption will be affected by a high density of the ciliates attached to the gills, regardless of the crayfish body weight.

\section{Materials and Methods}

\subsection{Animals}

Eighty Cambarellus (Cambarellus) montezumae crayfish were collected in Lago Xochimilco located at 19.261557 N and 99.078099 W, 2240 m.a.s.l. from January to April 2019. The animals were transported to the laboratory and kept in 25-liter aquaria, ten organisms per aquarium with constant aeration using air compressors (RA-806, Maxima ${ }^{\circledR}$, Santee, CA, USA), with a rocky substrate and plastic tubular shelters. To avoid physiological stress to the crayfish caused by the variation of the water chemistry, they were acclimatized for four days to the conditions of the water reported as optimal for the species, such as temperature $22^{\circ} \mathrm{C}, \mathrm{pH} 7.4$, and dissolved oxygen $4 \mathrm{mg} / \mathrm{L}$ [14] and fed with a commercial balanced shrimp feed (Camaronina, Purina ${ }^{\circledR}, 35 \%$ protein, Mexico). Before starting the measurement of oxygen consumption, they were fasted for $12 \mathrm{~h}$. Immediately after oxygen measurement, each crayfish was weighed with an electronic balance (07932-0900, OHAUS Corporation, Parsippany, NJ, USA) Crayfish ( $\overline{\mathrm{x}} 0.71 \mathrm{~g}, \mathrm{SD} 0.34 \mathrm{~g}$, range $\pm 0.6 \mathrm{~g})$ were grouped into three body weight classes: $1(0.2-0.6 \mathrm{~g}), 2(0.7-1.1 \mathrm{~g})$, and $3(1.2-1.6 \mathrm{~g})$, to analyze the relation between ciliate abundance in the gills and body weight.

\subsection{Oxygen Consumption}

After acclimation and fasting, crayfish were individually placed in a $125 \mathrm{~mL}$ glass respiratory chamber with dechlorinated tap water. Initial oxygen concentration was measured with a polarographic oximeter (HI9143, HANNA ${ }^{\circledR}$, USA), and the chamber was closed. After 50 minutes, the oxygen concentration was taken again. As controls, oxygen concentrations were also measured in chambers with $125 \mathrm{ml}$ water without a crayfish, initially and $50 \mathrm{~min}$ after closing the chamber. Oxygen consumption was calculated as the difference between the initial and final readings.

After oxygen measurement, crayfish were placed in an ice slurry to cause insensitivity and slaughtered using the splitting method [15]. Ciliates attached to the gill were counted, being each cell considered an individual. To ensure that gill ciliates were not released in the process of measuring oxygen consumption, the water of each chamber was examined with optical and stereoscopic microscopes.

\subsection{Identification of Ciliates}

For ciliate species identification, we followed protargol impregnation [16], a technique useful to show specific cellular characteristics of the zooids to determine species. Additionally, a light microscope (DIC) was used to obtain microphotographic records from zooids and colonies with a Nikon digital camera (Digital Sight DS2Mv, Nikon ${ }^{\circledR}$, Tokyo, Japan) adapted to a microscope (Labophot2/AX70, Nikon ${ }^{\circledR}$, Tokyo, Japan). For Scanning Electron Microscopy to show the details of the loriga and colonies organization, ciliates were separated and fixed in $4 \%$ formaldehyde for $24 \mathrm{~h}$ and washed with a buffer ( $\mathrm{pH} 7.3)$. A dehydration protocol was followed, dried to the critical point with $\mathrm{CO} 2$, mounted, and 
coated with gold [17]. Samples were observed with a microscope (SU 1510 10kV, Hitachi ${ }^{\circledR}$, Tokyo, Japan).

\subsection{Statistical Analysis}

A multiple linear regression test was conducted (SPSS 19.0) to determine if the oxygen consumption depends on the number of cells of ciliates attached to the crayfish gills and the weight of the organisms. The ANOVA test was performed to find significant differences between oxygen consumption and the number of cells of ciliates in gills. A contingency table was also made with Fisher's exact test between the three weight classes of the crayfish and the number of epibionts. These tests were applied with the 3.2.0 version of the $R$ program and the graphs drawn with Graphpad Prism 9.

\section{Results}

Ciliates attached to the gills of crayfish were identified as Cothurnia variabilis (Kellicott, 1883), and Epistylis gammari (Precht, 1935) (Figure 1). Only seven of eighty crustaceans collected $(8.75 \%)$ did not exhibit attached ciliates. Epistylis gammari presented a greater abundance with 4450 individuals counted, representing $67.5 \%$, while 2191 cells of $C$. variabilis were present, representing $32.5 \%$ of ciliates attached to the gills.
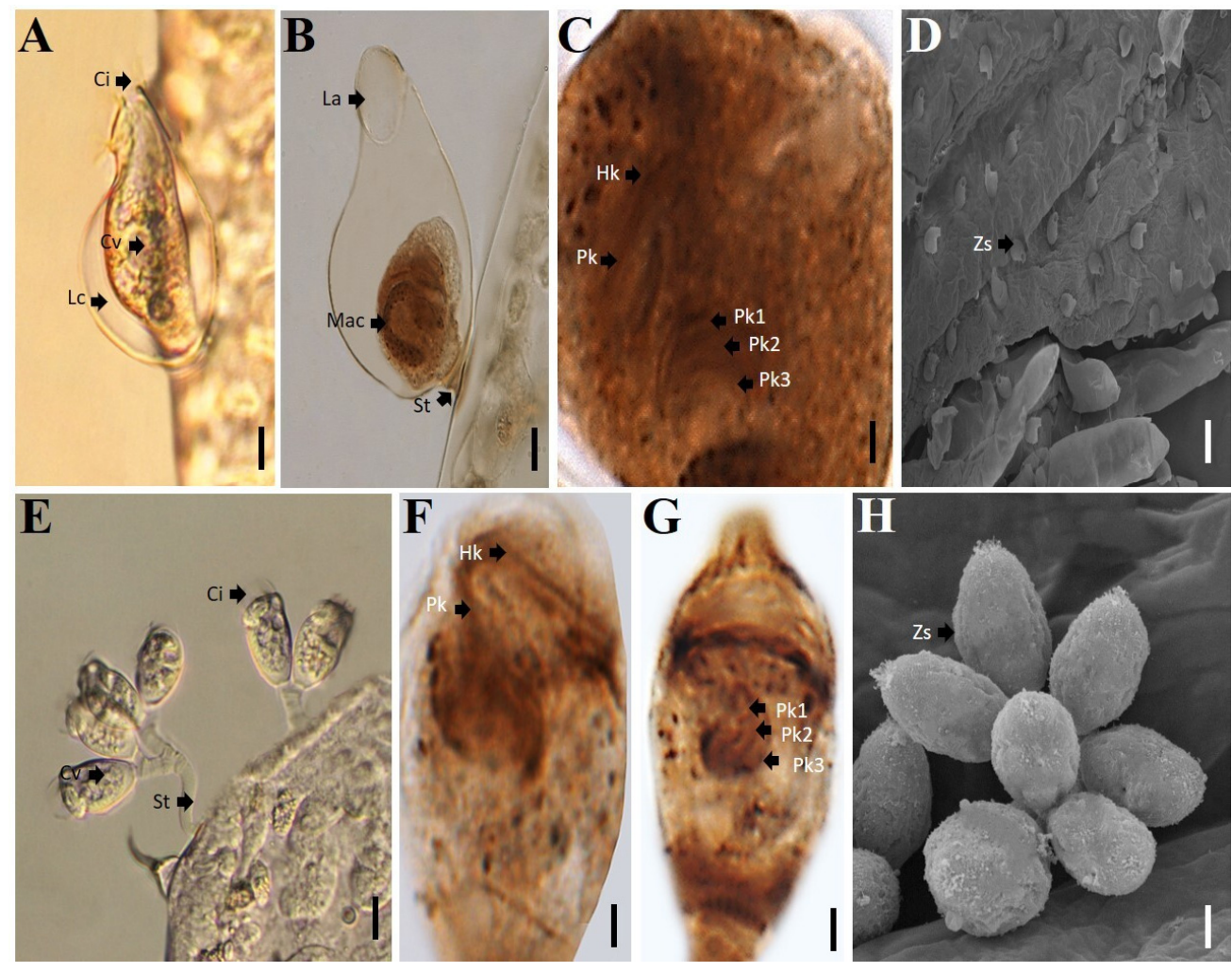

Figure 1. Ciliate epibionts in gills. (A-D). Cothurnia variabilis. (A,B). Detail of cell. (C). Oral ciliature after protargol impregnation. (D). Detail of cell in SEM. (E-H). Epistylis gammari. E. Colony attached to gills. (F,G). Oral ciliature after protargol impregnation. (H). Detail of the colony in SEM. Abbreviations: Ce. Cells; Ci. Cilia; Cv. contractile vacuole; Hk. haplokinety; La. Lorica aperture; Lc. Lorica; Mac. macronucleus; Pk. Polykinety; Pk 1. Polykinety 1; Pk 2. Polykinety 2; Pk 3. Polykinety 3; St. stalk. Scale bars: $5 \mu \mathrm{m}(\mathbf{A}, \mathbf{B}), 1 \mu \mathrm{m}(\mathbf{C}, \mathbf{F}, \mathbf{G})$ and $15 \mu \mathrm{m}(\mathbf{D}), 20 \mu \mathrm{m}(\mathbf{E}), 10 \mu \mathrm{m}(\mathbf{H})$.

\section{Oxygen Consumption}

Linear and multiple regression analyses showed a highly significant relationship between oxygen consumption rate and the number of ciliates attached to gills $(p<0.05)$ (Figure 2, Table 1). The crayfish with the higher number of ciliates (220 to 260) exhibited the highest metabolic rate, significantly different from those without ciliates $(p<0.05)$. 


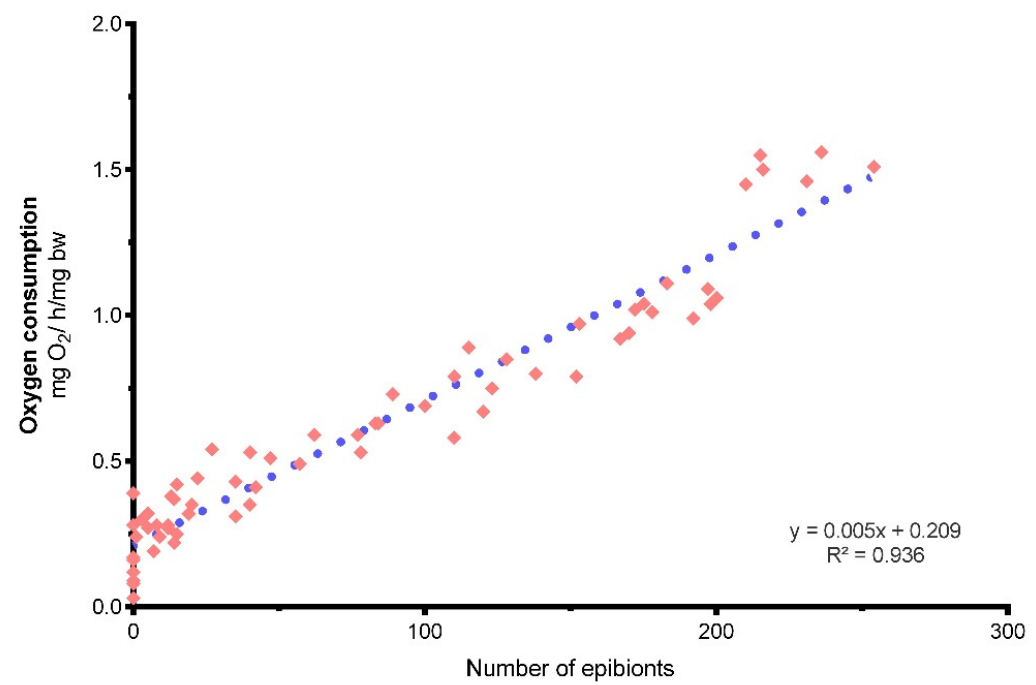

Figure 2. Relation between oxygen consumption and the number of epibionts attached to the gills of crayfish.

Table 1. Multiple regression analysis of oxygen consumption vs. number of zooids in gills and crayfish body weight.

\begin{tabular}{ccccc}
\hline Coefficients & Estimate & Std. Error & $\mathbf{t}$ & $\mathbf{p}$ \\
\hline Intercept & 0.177 & 0.036 & 4.856 & 0.000 \\
Nunber of zooids & 0.005 & 0.000 & 29.274 & 0.000 \\
Crayfish weight & 0.060 & 0.037 & 1.615 & 0.110 \\
\hline
\end{tabular}

Residuals: Min: -0.17117, Mean: 0.000, Max: 0.26113; Multiple $\mathrm{R}^{2}=0.933$, Adjusted $\mathrm{R}^{2}=0.931$; F statistics $=532.565$ on 2 and 77 FD $p=0.0001$.

We found that 50 ciliate epibionts up is the number causing an increase of oxygen consumption of the crayfish, as compared with the $8.7 \%$ that had no ciliates attached to the gills, showing a significant difference $(p<0.05)$ in oxygen consumption from $\sim 50$ cells on attached to the gills.

It was observed that the crayfish with lower body weight exhibited a greater abundance of epibiont ciliates attached to the gills (Figure 3). The correlation of oxygen consumption versus the number of cells of ciliates was independent of crayfish body mass, with high variation in ciliate incidence found at lower body weights (Table 1). Although the specific metabolic rate seems to correlate negatively with crayfish body weight (Figure 4), it is not statistically significant (Table 1 ).

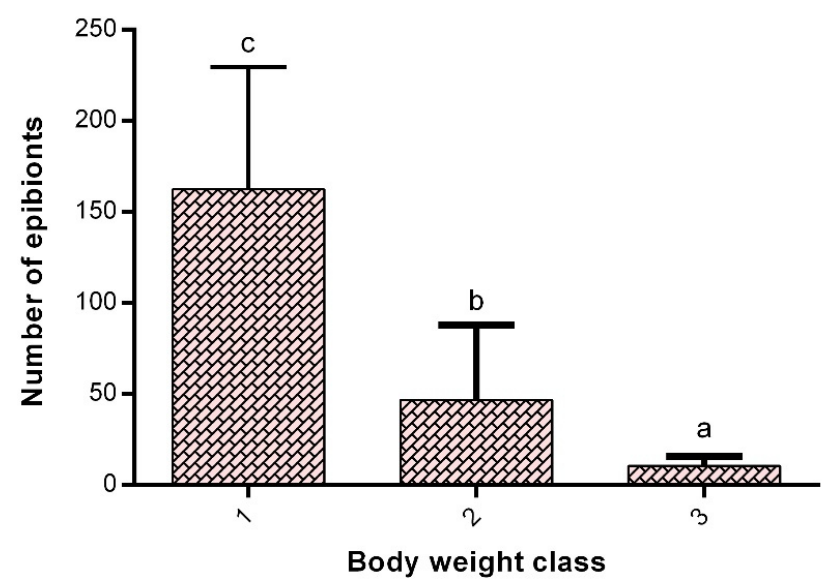

Figure 3. Crayfish body weight $\mathrm{s}$ and the number of branchial epibionts. Class 1: $0.2-0.6 \mathrm{~g}(\mathrm{n}=30)$, 2: $0.7-1.1 \mathrm{~g}(\mathrm{n}=27)$, and 3: $1.2-1.6 \mathrm{~g}(\mathrm{n}=23)$. Different letter between bars indicates significant difference $(p<0.05)$. 


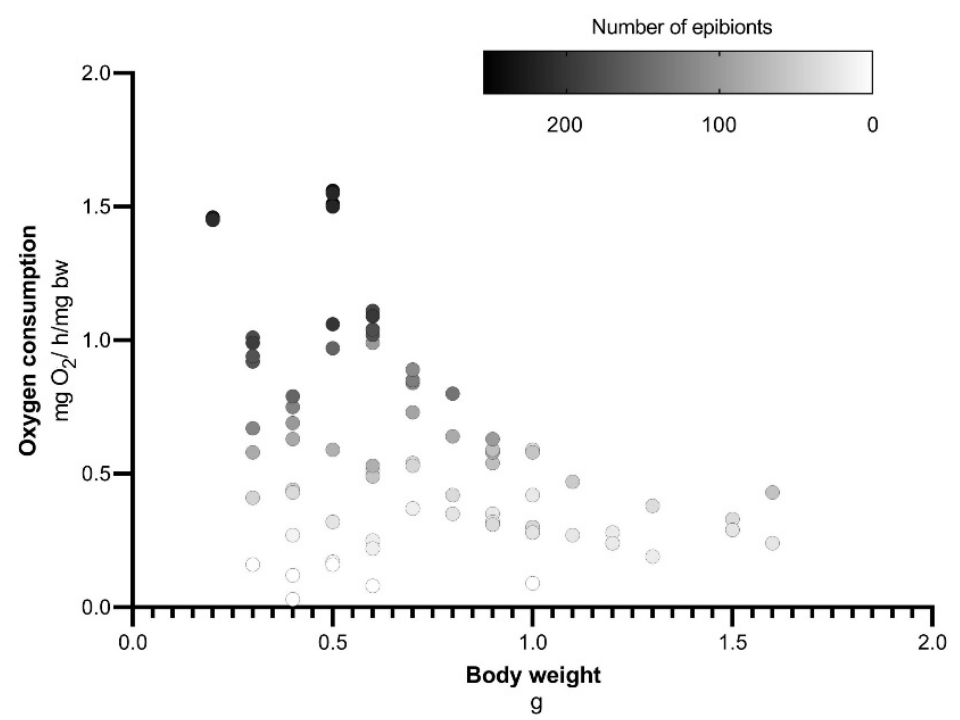

Figure 4. Oxygen consumption and body weight of the crayfish with different number of ciliates attached to the gills.

\section{Discussion}

The present results demonstrate a relationship between the oxygen consumption of this crayfish species and the epibiotic load of peritrichs in its gills. There is a significant increase in oxygen consumption as more cells of ciliates adhere to the gills. Since the gills of crustaceans are multifunctional organs with several physiological processes, ciliates could substantially affect these processes. One is ion transport, the basis for osmoregulation, acid-base balance, and ammonia excretion [18].

During the respiration of decapod crustaceans, water enters the gill chamber and circulates over its surfaces. This stream of water exposes the gills to an accumulation of particulate debris and mobile phases of epibiont organisms $[19,20]$. Through this stream of water, colonization of the gills by epibiont ciliates takes place. The telotroch larvae of epibiotic peritrichs get attached to the gills and settle once the stalk is secreted.

The two ciliate species attached to the gills are peritrichs, which have similar feeding and attachment strategies [21], so they have the same opportunities to colonize the gills. These similar strategies were confirmed in the present study since no crayfish with only one species attached to the gills was found. Both species of ciliates were always present, so the effect of a single species could not be analyzed. Epistylis gammari is more abundant than $C$. variabilis, and for that reason, it may have a higher effect on altering respiration. However, Vogelbein and Thune [22] mentioned that Cothurnia sp. causes minor interference than Epistylis sp., based on their attachment ultrastructure.

The increase in oxygen consumption may be due to the energy expenditure involved to repair the gill damage. Some cases have been documented where the ciliates cause some damage to the epithelium of the gills. Couch [23] reported that the peritrich Lagenophrys callinectes (Couch, 1967), occasionally caused a brown pigmentation at the gill site of attachment of the crab Callinectes sapidus (Rathbun, 1896). In heavy infestations, the cell and the ciliate's lorica could partially interfere with the gill membrane's normal diffusion of gases. Messick [24] reported that the ciliates L. callinectes and Epistylis sp. caused some lesions, such as the accumulation of hematocytes and shedding of epithelial cells from the cuticle of the C. sapidus gill.

Not only do the ciliates adhere to the gills of decapod crustaceans, but also some other organisms can be attached to this crustacean organ, causing some damage, and affecting respiratory function. For example, Davis et al. [25] found that the copepod Nicothoe astaci (Audouin and Edwards, 1826), in addition to feed of the hemolymph, can damage the gills, potentially affecting the gas exchange capacity due to physical damage to the gills. 
Robles et al. [26] recorded an increase in the respiratory rate of Callinectes rathbunae (Contreras, 1930), where the barnacle Loxothylacus texanus (Boschma, 1933), parasitized the gills and found that the crabs from different salinities, with mature parasites, had significantly higher oxygen consumption rates than control crabs. Poulter et al. [27] reported the blue mussel Mytilus edulis (Linnaeus, 1758), which inhabits the gill chamber of the crab Carcinus maenas (Linnaeus, 1758). The attachment of M. edulis to the gills and the debris produced by the mussels could reduce respiratory efficiency by obstructing the water flow stream, impairing gill movements, and reducing the area of the exposed gill surface.

However, respiratory rate can be so sensitive that it is modified by a wide variety of internal and external factors. The increase in crayfish' metabolic rate may also be due to the stress generated by the ciliates attached to their gills. Wendelaar-Bonga [28] mentioned that in response to stress, animals increase oxygen consumption since it increases cardiovascular activity, and there is a change in osmoregulation.

Another possible cause for the increased metabolic rate caused by the ciliates is a higher muscular activity derived from the cleaning mechanisms of the gills. Decapod crustaceans have various mechanisms and structures for cleaning the gills and the gill chamber to maintain optimal gill function [19]. The active (direct) cleaning mechanism is the insertion of an appendage into the gill chamber to scrap the gills. In the passive mechanism, decapods frequently move their appendages during resting periods; the movement of these appendages cleans the gill surfaces [19].

Wortham and Pascual [29] studied the cleaning behaviors of two brachyuran crabs. They found that both species frequently use an active mechanism to clean the gills and the gill chamber. Becker and Walh [30] found that the brachyuran crab Charybdis (Charybdis) anisodon (De Haan, 1850), eliminates epibiont ciliates through grooming.

Bauer [19] and Fleischer et al. [20] mentioned that the active mechanism is more effective in preventing epibiosis than passive cleaning. This grooming activity could also explain the increase in the metabolic rate in the crayfish in the present study.

The oxygen consumption per unit of body weight, i.e., specific metabolic rate has an inverse relationship with body weight [31]. This inverse relationship was not observed in our study, since the range of body weights was small. The number of ciliate cells has a higher effect in metabolic rate than animals body weight, which are practically within the same order of magnitude (Figure 4). The crayfish with lower body weight have the highest ciliates load, this could be due to low growth in the most infested animals or to a preference for epibionts to adhere to young animals.

Brown et al. [32] mentioned that the relationships between species are in a continuous dynamic change from parasitism to mutualism. These relationships depend on the biotic conditions, abundance, and identity of the interacting organisms and abiotic conditions.

Therefore, the epibiosis of ciliated crayfish can change depending on several factors; if available food is scarce, the ciliate will seek another substrate once the telotroch is formed. Another factor to consider for the epibiotic system is the life cycle of the basibiont. If the crayfish enters the molting period, the ciliates immediately originate the larvae and leave the gills [33].

Furthermore, the age and size of the basibiont are crucial for epibionts. Juvenile basibiont have more movement than older organisms, resulting in a lower epibiont load and less susceptibility to colonization by ciliates [34].

Regarding the size of the crustaceans, the larger organisms present a greater surface area for the colonization of ciliates [34]. However, in our study, small individuals exhibited the highest number of epibionts.

This ciliate-crustacean epibiotic relationship can indirectly alter the aquatic ecosystem since it has been observed that the crayfish Camballerus is used as a trade-in aquatic animal, such as the case of C. patzcuarensis that was recorded in Hungary [35], if these crustaceans are transferred to places outside their place of origin, they can transport their epibionts, and they can be an invasive species, both the basibiont and its epibionts. 


\section{Conclusions}

In conclusion, Cothurnia variabilis and Epistylis gammari ciliate epibionts attached to the gill of the crayfish Cambarellus (Cambarellus) montezumae cause an increase in metabolic rate. This ciliate-crayfish epibiosis may have no effect on interacting organisms or be classified as parasitism depending on the number of gill-attached ciliates since low densities do not affect gas exchange, but high densities do.

Future studies would be necessary to determine the energy balance using the complete bio-energetics equation to estimate the global effect of ciliates attached to crustaceans. This study presents the basis of the effect of ciliates on oxygen consumption by crayfish, showing the importance of this type of research.

Author Contributions: Conceptualization: M.R.-B. and R.M.-E.; Methodology: M.R.-B., R.M.-E., A.L.V., and R.C.-V.; Formal Analysis: M.R.-B., A.L.-V., and R.C.-V.; Investigation: M.R.-B. and R.M.-E.; Resources: R.M.-E. and R.C.-V.; Data Curation: M.R.-B., A.L.-V., R.C.-V., and R.M.-E.; WritingOriginal Draft Preparation: M.R.-B.; Writing—Review and Editing: R.M.-E., A.L.-V., and R.C.-V.; Visualization: M.R.-B. and R.M.-E.; Supervision: R.M.-E., A.L.-V., and R.C.-V.; Project Administration: R.M.-E. All authors have read and agreed to the published version of the manuscript.

Funding: This research received no external funding.

Institutional Review Board Statement: The study was conducted according to the guidelines of the Declaration of Helsinki and approved by the Centro de Investigaciones Biológicas y Acuícolas de Cuemanco with authorization X-ERG-564-67-CIBAC-35573.

Data Availability Statement: Publicly available datasets were analyzed in this study. This data can be found here: [https://data.world/mballesteros/data-2021-effect-of-epibiosis-on-metabolic-rate accessed on 7 June 2021 Effect of epibiosis on metabolic rate].

Acknowledgments: To Posgrado en Ciencias Biológicas, UNAM, and CONACyT for a grant to MRB. Thanks to M. B. Mendoza-Garfias (LMF1-LaNaBio) for the support in obtaining SEM images. We also appreciate the technical support of MS I. A. Morales-Salas and Biól. M. Reyes-Santos † (Facultad de Ciencias, UNAM). Special thanks to Gaytha A. Langlois (Department of Science \& Technology, Bryant University) for her comments and assistance with the English language.

Conflicts of Interest: The authors declare no conflict of interest. All authors have read and agreed to the published version of the manuscript.

\section{References}

1. Olson, R.J.; Young, J.W.; Ménard, F.; Potier, M.; Allain, V.; Goñi, N.; Logan, J.M.; Galván-Magaña, F. Bioenergetics, trophic ecology, and niche separation of tuna. In Advances in Marine Biology; Curry, B., Ed.; Elsevier: Cambridge, MA, USA, 2016; Volume 74, pp. 199-344. ISBN 9780128036075.

2. Kawai, T.; Patoka, J. Gill morphology and formulae of crayfishes (Decapoda: Astacidea: Parastacidae) from New Guinea and New Zealand and a comparison with other selected species of crayfishes. J. Crust. Biol. 2021, 41, 1-11. [CrossRef]

3. Ali, M.; Salman, D.; Abdul-Hussain, Y. Oxygen consumption of the freshwater crab Elamenopsis kempi (Chopra and Das, 1930) from the Garmat Ali river, Iraq. Sci. Mar. 2000, 64, 311-317. [CrossRef]

4. Villareal, H.; Hernández-Llamas, A.; Hewitt, R. Effect of salinity on growth, survival and oxygen consumption of juvenile brown shrimp Farfantepenaeus californiensis (Holmes). Aquac. Res. 2003, 34, 187-193. [CrossRef]

5. Brito, R.; Chimal, M.; Rosas, C. Effect of salinity in survival, growth, and osmotic capacity of early juveniles of Farfantepenaeus brasiliensis (Decapoda: Penaeidae). J. Exp. Mar. Biol. Ecol. 2000, 244, 252-263. [CrossRef]

6. Salvato, B.; Cuomo, V.; Di Muro, P.; Beltramini, M. Effects of environmental parameters on the oxygen consumption of four marine invertebrates: A comparative factorial study. Mar. Biol. 2001, 138, 659-668. [CrossRef]

7. Farrell, A.P. Pragmatic perspective on aerobic scope: Peaking, plummeting, pejus and apportioning. J. Fish Biol. 2016, 88, 322-343. [CrossRef]

8. Wahl, M. Ecological lever and interface ecology: Epibiosis modulate the interactions between host and environment. Biofouling 2008, 24, 27-38. [CrossRef] [PubMed]

9. Ďuriš, Z.; Horká, I.; Petrusek, A. Invasive zebra mussel colonisation of invasive crayfish: A case study. Hydrobiologia 2007, 590, 43-46. [CrossRef]

10. Harder, T. Marine epibiosis: Concepts, ecological consequences, and host defense. In Marine and Industrial Biofouling; Flemming, H., Sriyutha, P., Venkatesan, R., Cooksey, K., Eds.; Springer: Los Angeles, CA, USA, 2009; pp. 219-232. ISBN 978-3-540-69796-1. 
11. Skelton, J.; Doak, S.; Leornard, M.; Creed, P.; Brown, L. The rules for symbionts community assembly change along a mutualismparasitism continuum. J. Anim. Ecol. 2016, 85, 543-853. [CrossRef] [PubMed]

12. Lightner, D.V. Diseases of cultured penaeid shrimps. In Handbook of Mariculture, Crustacean Aquaculture, 2nd ed.; McVey, J.P., Moore, J.R., Eds.; CRC Press: Boca Raton, FL, USA, 1988; Volume 1, pp. 289-320. ISBN 9780849302558.

13. Overstreet, R.M. Parasites of some penaeid shrimp with emphasis on reared hosts. Aquaculture 1973, 2, 105-140. [CrossRef]

14. Arredondo-Figueroa, J.L.; Ponce-Palafox, J.; Hernández-Ocampo, D.; Rodríguez-Chávez, G.; Benítez-Mandujano, M. Aspectos básicos del cultivo del acocil Cambarellus (Cambarellus) montezumae (Crustacea: Decapoda: Cambaridae) en condiciones controladas. Ind. Acuícola. Acuacultura Neg. México 2015, 2, 44-48.

15. Yue, S. The Welfare of Crustaceans at Slaughter. Impacts on Farm Animals 4. 2008. Available online: https://www. wellbeingintlstudiesrepository.org/hsus_reps_impacts_on_animals/4 (accessed on 6 April 2021).

16. Foissner, W. Basic light and electron microscopic methods for taxonomic studies of ciliated protozoa. Eur. J. Protistol. 1991, 27, 313-330. [CrossRef]

17. Sorrivas de Lozano, V.; Morales, A.; Yañez, J. Principios y Práctica de la Microscopía Electrónica, 1st ed.; UAT-CONICET: Buenos Aires, Argentina, 2014; ISBN 978-987-43-4752-7.

18. Henry, R.; Lucu, C.; Onken, H.; Weihrauch, D. Multiple functions of the crustacean gill: Osmotic/ionic regulation, acid-base balance, ammonia excretion, and bioaccumulation of toxic metals. Front. Physiol. 2012, 3, 431. [CrossRef]

19. Bauer, R. Gill-cleaning mechanisms of the crayfish Procambarus clarkii (Astacidea: Cambaridae): Experimental testing of setobranch function. Invertebr. Biol. 1998, 117, 129-143. [CrossRef]

20. Fleischer, J.; Grell, M.; Høeg, T.; Olesen, J. Morphology of grooming limbs in species of Petrolisthes and Pachycheles (Crustacea: Decapoda: Anomura: Porcellanidae): A scanning electron microscopy study. Mar. Biol. 1992, 113, 425-435. [CrossRef]

21. Lynn, D.H. Ciliophora. In Handbook of the Protists; Archibald, J.M., Simpson, A.G.B., Slamovits, C.H., Eds.; Springer: Cham, Switzerland, 2017; pp. 679-730. ISBN 978-3-319-28148-3.

22. Vogelbein, E.; Thune, R. Ultrastructural features of three ectocommensal protozoa attached to the gills of the red swamp crawfish, Procambarus clarkii (Crustacea: Decapoda). J. Protozool. 1988, 35, 341-348. [CrossRef]

23. Couch, J.A. A New Species of Lagenophrys (Ciliatea: Peritrichida: Lagenophryidae) from a marine crab, Callinectes sapidus. Trans. Am. Microsc. Soc. 1967, 86, 204-211. [CrossRef]

24. Messick, G. Diseases, parasites, and symbionts of blue crabs (Callinectes sapidus) dredged from Chesapeake Bay. J. Crust. Biol. 1998, 18, 533-548. [CrossRef]

25. Davis, C.; Vogan, C.; Rowley, A. Effect of the copepod parasite Nicothoë astaci on haemolymph chemistry of the European lobster Homarus gammarus. Dis. Aquat. Organ. 2015, 113, 169-715. [CrossRef]

26. Robles, R.; Alvarez, F.; Alcaraz, G. Oxygen consumption of the crab Callinectes rathbunae parasitized by the rhizocephalan barnacle Loxothylacus texanus as a function of salinity. Mar. Ecol. Prog. Ser. 2002, 235, 189-194. [CrossRef]

27. Poulter, R.; Oliver, P.G.; Hauton, C.; Sanders, T.; Ciotti, B. Infestation of shore crab gills by a free-living mussel species. Mar. Biodiv. 2018, 48, 1241-1246. [CrossRef]

28. Wendelaar-Bonga, S.E. The stress response in fish. Physiol. Rev. 1997, 77, 591-625. [CrossRef]

29. Wortham, J.; Pascual, S. Grooming behaviors and gill fouling in the commercially important blue crab (Callinectes sapidus) and stone crab (Menippe mercenaria). Nauplius 2017, 25, e2017028. [CrossRef]

30. Becker, K.; Wahl, M. Behaviour patterns as natural antifouling mechanisms of tropical marine crabs. J. Exp. Mar. Biol. Ecol. 1996, 203, 245-258. [CrossRef]

31. Valbuena, R.; Cruz, P. Efecto del peso corporal y temperatura del agua sobre el consumo de oxígeno de tilapia roja (Oreochromis sp). Orinoquia 2006, 10, 57-63. [CrossRef]

32. Brown, B.L.; Creed, R.P.; Skelton, J.; Rollins, M.A.; Farrell, K.J. The fine line between mutualism and parasitism: Complex effects in a cleaning symbiosis demonstrated by multiple field experiments. Oecologia 2012, 170, 199-207. [CrossRef]

33. Utz, L.; Coats, W. Telotroch formation, survival, and attachment in the epibiotic peritrich Zoothamnium intermedium 318 (Ciliophora, Oligohymenophorea). Invertebr. Biol. 2008, 127, 237-248. [CrossRef]

34. Fernandez-Leborans, G. Epibiosis in Crustacea: An overview. Crustaceana 2010, 83, 549-640. [CrossRef]

35. Weiperth, A.; Gál, B.; Kuříková, P.; Bláha, M.; Kouba, A.; Patoka, J. Cambarellus patzcuarensis in Hungary: The first dwarf crayfish established outside of North America. Biología 2017, 72, 1529-1532. [CrossRef] 